\title{
Translocation of Harpy Eagle (Harpia harpyja) (Linnaeus, 1758) nest
}

\author{
A. A. Kuniy *, M. A.Viana ${ }^{a}$, T. M. G. Zahn ${ }^{b}$, D. E. A. Lazarinos ${ }^{a}$ and C. E. B. Portes ${ }^{a, c}$ \\ aJGP Consultoria e Participações Ltda, Rua Américo Brasiliense, 615, CEP 04715-003, São Paulo, SP, Brazil \\ 'Instituto de Biociências, Universidade de São Paulo - USP, Rua do Matão, 14, Butantã, \\ CEP 05508-090, São Paulo, SP, Brazil \\ `Museu Paraense Emílio Goeldi, CP 399, CEP 66040-170, Belém, PA, Brazil \\ *e-mail: adriana.akemi@jgpconsultoria.com.br
}

Received: December 8, 2014 - Accepted: February 5, 2015 - Distributed: November 30, 2015

For most birds, the nest is only a temporary structure that cannot be reused, not even for the same breeding season (Aguilar and Marini, 2007). However, the practice of reusing the nests is a typical behavior of hawks. The aim of this note is to describe the procedures taken for translocating a Harpy Eagle (Harpia harpyja Linnaeus, 1758) nest located in an arboreal specimen (Dinizia excelsa) approximately 45 meters high found within the future right of way of an electric power transmission line in the municipality of Manaus, State of Manaus, Brazil. This species is under Near Threatened status according to the IUCN (2014). The breeding period for Harpy Eagles is usually coincident with the start of the rainy season, usually between April and May (Galetti and Carvalho Junior, 2000). The nests, measuring up to $2 \mathrm{~m}$ in diameter, are built by the breeding pair together using thick twigs, in trees 50-70m high emerging from the canopy (Del Hoyo et al., 1994). The position chosen for the nest is usually the main branch of a tree at a height ranging from 25 to 35 meters (Piana, 2007). According to Alvarez-Cordero (1996), each breeding pair is linked to a territory centred on the nests, enabling one to calculate the mean breeding area for a pair. Each breeding pair usually incubates 1 to 2 eggs per clutch in what is considered one of the longest bird reproductive cycles (Aparicio, 2002). Females are responsible for $97 \%$ of the incubation, and the usual reproductive success is 1 egg per clutch (Del Hoyo et al., 1994). In May, 2012, an active Harpy Eagle nest was spotted approximately 45 meters high atop a Dinizia excelsa tree at $60^{\circ} 00^{\prime} 37.4939^{\prime \prime}$ W/ $2^{\circ} 55$ ' 24.4053" S (WGS 84), in the municipality of Manaus (AM). A single hatchling was seen in the nest being fed by its parents in the course of the period of observations. Initial characterisation of the need for translocation was linked to the nest being located within the right of way of a future electric power transmission line. A total of 52 surveys were carried out to follow the hatchling's development and further assess and ascertain the necessity for the translocation procedure, comparing risks and benefits to alternative managing approaches. Observations made in the period between May and August, 2012 attested the hatchling's dependence on the nest. A concerted effort by the consultants responsible for the environmental management and the company in charge of the transmission line construction led to a 10 month suspension of construction activities in the area surrounding the nest, time enough to allow the hatchling to reach a developmental stage such that the bird could fly to adjacent areas. Starting in September, 2013, the young could fly to trees surrounding the nest up to an approximate distance of $50 \mathrm{~m}$. From January, 2013 onward, the parent's absence from the nest was also noticed, a natural behaviour believed to stimulate the young Harpy Eagle to forage on its own (Luis Fábio Silveira, personal orientation at the Zoological Museum, 2012). Surveys carried out in February, 2013 found the young still roosting on the arboreal specimen housing the nest. At about the same time, the progress of cable stringing activities led to confirmation of the need for removal of the nest-bearing tree. Experimental controlled disturbance procedures were carried out as a further test of the young Harpy Eagle's dependence on the tree housing the nest. The team responsible for such activities employed loud shrill noise emissions next to the D. excelsa tree in an attempt to displace the young bird. After the procedure, displacements of up to 100 metres towards the surroundings have been detected, confirming the bird's capacity to move around on its own. The final decision for the necessity of the translocation procedure was taken during the final stage of the aforementioned surveys, and took into consideration the fact that Harpy Eagle parents are loyal to nesting sites. Three arboreal specimens with heights similar to the tree originally housing the nest were considered as possible sites for translocation. The final decision favoured the tree nearest to its previous location, at $2^{\circ} 55^{\prime} 21.8304 " \mathrm{~S} / 60^{\circ} 00^{\prime} 35.4626^{\prime \prime} \mathrm{W}$ (WGS 84). The translocation itself took place on March $14^{\text {th }}$. Prior disturbance procedures using noise emissions as described above started at 07:00 a.m. and led to the young bird's displacement from the tree to the surrounding area, as detected by the team responsible. A professional climber was hired to climb the tree and retrieve the nest. The young Harpy Eagle screamed loudly during the climber's ascent, thus attracting its parents, which flew closer, a behaviour also registered in Rettig (1978)'s study. Following inspections, the nest was determined to be relatively aged, which complicated its handling. Due to such difficulties, a portion of the nest was damaged when trying to detach and retrieve it. Nonetheless, prior to the descent from the tree and its clearance to be felled, a significant part of the nest's material was retrieved and later used as a base for the new nest. Steel cables, 
attached to the tree as the climber descended, were later fastened to the ground and tractionated using the necessary equipment (tirfor winch) to direct the falling tree towards the right of way. The felling was performed only after the cables were fastened, and the tree was gradually lowered to the ground. A bait was set on the newly translocated nest in order to lure the young Harpy Eagle to the newly translocated nest. After the translocation procedure, the young bird was spotted again at a distance of $200 \mathrm{~m}$ from the old nest site, but it was not seen approaching the new nest at the time. Weekly surveys of the translocated nest area have been recommended after the procedure in order to inspect its effectiveness, identifying approximation of the Harpia harpyja young and/or their parents to the tree housing the new nest or, alternatively, approaching other bird species which may come to use the implanted nest in breeding.

\section{Acknowledgements}

We extend our thanks to Centrais Elétricas do Brasil S.A; Giuliano Almeida; Dione Serripieri, Andrew Whitaker, Jaqueline Fortuna and Luis F. Silveira.

\section{References}

AGUILAR, T.M. and MARINI, A.M., 2007. Nest and nest-site reuse within and between breeding seasons by three neotropical flycatchers (Tyrannidae). Brazilian Journal of Biology $=$ Revista
Brasileira de Biologia, vol. 67, no. 3, pp. 537-540. http://dx.doi. org/10.1590/S1519-69842007000300020. PMid:18094838.

ALVAREZ-CORDERO, E., 1996. Biology and conservation of the Harpy Eagle in Venezuela and Panama. Gainesville: University of Florida, 212 p. Doctoral Thesis in Philosophy.

APARICIO, K.M., 2002. Historic and present distribution of the Harpy Eagle (Harpia harpyja) in Panama. In: Program of the Conference on Neotropical Raptors and Symposium on the Harpy Eagle, October 2002, Panamá City, Panamá. Panamá: Fondo Peregrino, pp. 24-83.

DEL HOYO, J., ELLIOT, A. and SARGATAL, J., 1994. New world vultures to guineafowl. Barcelona: Lynx Edicions. 640 p. Handbook of the Birds of the World, vol. 2.

GALETTI, M. and CARVALHO JUNIOR, O., 2000. Sloths in the diet of a Harpy Eagle nestling in eastern Amazon. The Wilson Bulletin, vol. 112, no. 4, pp. 535-536. http://dx.doi. org/10.1676/0043-5643(2000)112[0535:SITDOA]2.0.CO;2.

INTERNATIONAL UNION FOR CONSERVATION OF NATURE AND NATURAL RESOURCES - IUCN, 2014 [viewed 13 November 2014]. IUCN Red List of Threatened Species. Version 2014.1 [online]. Available from: www.iucnredlist.org.

PIANA, R.P., 2007. Anidamiento y dieta de Harpia harpyja Linnaeus en la Comunidad Nativa de Infierno, Madre de Dios, Peru. Revista Peruana de Biología, vol. 14, no. 1, pp. 135-138.

RETTIG, N., 1978. Breeding behavior of the Harpy Eagle (Harpia harpyja). The Auk, vol. 95, pp. 629-643. 